\title{
Sand flies (Diptera, Psychodidae, Phlebotominae), vectors of Leishmania protozoa, at an Atlantic Forest Conservation Unit in the municipality of Nísia Floresta, Rio Grande do Norte state, Brazil
}

Marcos Paulo Gomes Pinheiro, Marcel Miranda de Medeiros Silva, João Batista Silva Júnior, José Hilário Tavares da Silva, Maria de Lima Alves and Maria de Fátima Freire de Melo Ximenes*

\begin{abstract}
Background: Sand flies are insect vectors of protozoa from the genus Leishmania, causative parasites of visceral and American tegumentary leishmaniases. The present study discusses the bioecological aspects of sand fly species, transmitters of Leishmania protozoa, in different ecotopes of an Atlantic Forest Conservation Unit located in the metropolitan region of Natal, Rio Grande do Norte state, Brazil.

Methods: Two monthly captures were made in 1 year, using CDC light traps, in two anthropized and two preserved environments.

Results: A total of 2936 sand flies belonging to the following ten species were captured: Evandromyia walkeri, Evandromyia evandroi, Psychodopygus wellcomei, Sciopemyia sordellii, Psathyromyia brasiliensis, Lutzomyia longipalpis, Evandromyia lenti, Psathyromyia shannoni, Nyssomyia whitmani and Nyssomyia intermedia. The most common species was E. walkeri $(77.6 \%)$, followed by E. evandroi (17.5\%). Forest was the site with the greatest abundance (32.4\%), followed by bamboo grove (26.3\%).

Conclusions: Sand flies were generally more abundant in the rainy season and L. longipalpis, a vector species of Leishmania infantum, was adapted to anthropized environments. It was confirmed that $P$. wellcomei, a vector of Leishmania braziliensis in Amazônia, is a species associated with more preserved environments, and occurs only in the rainy season.
\end{abstract}

Keywords: Sand flies, Lutzomyia, Psychodopygus, Nyssomyia, Visceral leishmaniasis, American tegumentary leishmaniasis, Atlantic forest

\footnotetext{
*Correspondence: ximenes@cb.ufrn.br

Laboratório de Entomologia, Centro de Biociências, Universidade Federal do Rio Grande do Norte, Avenida Senador Salgado Filho, 3000 Natal, Rio Grande do Norte, Brazil
} 


\section{Background}

Sand flies are insects responsible for transmitting the causative parasites of American tegumentary (ATL) and visceral leishmaniases (VL), a serious health problem and among the major human diseases transmitted by insect vectors that can cause mutilation, incapacity and death $[1,2]$.

Although cutaneous and mucosal leishmaniasis are endemic to 18 countries in the Americas, with cases ranging from Mexico to Argentina, most cases are concentrated in Brazil and the Andean subregion [3].

$\mathrm{VL}$ is endemic to Latin America and most cases occur in Brazil, with risk factors also found in Argentina, Bolivia, Colombia, Costa Rica, El Salvador, Guatemala, Honduras, Mexico, Nicaragua and Venezuela [3].

In Brazil, the etiologic agent of VL is the protozoan Leishmania infantum and the vector is the sand fly Lutzomyia longipalpis [4]. ATL exhibits different causative agents and vectors, depending on the region of the country [5-12]. Among the sand flies considered vectors of ATL in Brazil, Nyssomyia whitmani, Nyssomyia intermedia, Nyssomyia umbratilis, Migonemyia migonei, Psychodopygus complexa and Psychodopygus wellcomei occur in the Northeast [6, 12-15]. Effective measures to control the vectors are increasingly necessary.

Leishmaniasis transmission occurs in all regions of Brazil, with the largest number of VL cases recorded in the Northeast (53.6\% of confirmed cases), where the disease, formerly restricted to rural areas, has expanded to periurban and urban regions $[4,16]$. In recent years, it has spread to urban areas throughout the country, and is continuously advancing in 21 states [17].

ATL occurs in all regions of Brazil, with outbreaks in the South, Southeast, Midwest, Northeast and North, primarily in the Amazon, where it is associated with colonization processes in areas deforested to construct roads, new urban centers and expand agricultural activities $[18,19]$.

In Rio Grande do Norte, cutaneous leishmaniasis is caused by Leishmania braziliensis [5] and occurs predominantly in the highland area of the state, primarily in municipalities at altitudes between 500 and $700 \mathrm{~m}$. VL is more common in the Metropolitan region, where $37 \%$ of the cases were recorded between 2007 and 2014, but can also be found in municipalities in the Western region of the state, which has reported a significant number of cases in recent years [5, 20-22].

This study aimed to determine the composition of sand fly fauna in different ecotopes of an Atlantic Forest fragment, in order to broaden knowledge of the vector species, thereby contributing to epidemiological surveillance and control in the state.

\section{Methods}

Study area

The study was conducted in the National Forest (FLONA) of Nísia Floresta, an Atlantic Forest Conservation Unit located in the municipality of Nísia Floresta, Rio Grande do Norte state, Brazil. It is situated $30 \mathrm{~km}$ from the state capital, encompasses an area of $307,839 \mathrm{~km}^{2}$, with a population of 26,208 inhabitants in 2014, according to the Brazilian Institute of Geography and Statistics [23].

The Nísia Floresta FLONA is located in a region historically exploited for sugarcane monoculture. It is a conservation and research unit with 168.84 ha of different exotic and native Atlantic Forest plant cover [24].

Collections occurred at four specific points, denominated bamboo (1), trail (2), forest (3) and pinery (4), approximately $300 \mathrm{~m}$ apart (Fig. 1).

Bamboo (S06 05'13.9"/W035 $\left.{ }^{\circ} 11^{\prime} 09.1^{\prime \prime}\right)$ and trail (S06 $\left.05^{\prime} 09.2^{\prime \prime} / \mathrm{W} 035^{\circ} 11^{\prime} 06.5^{\prime \prime}\right)$, the closest points to the FLONA administration building, are more affected by anthropic activity.

The former (1) is significantly impacted and characterized by a number of bamboo plants (Poaceae: Bambusoideae) in a $900 \mathrm{~m}^{2}$ clearing containing litter and decomposing branches, in addition to discarded plant trimmings.

The latter (2) contains native trees such as Tabebuia sp. (ipê), Caesalphinia echinata (Brazilwood), Caesalpinia ferrea (Brazil ironwood), Bauhinia forficata (Brazilian orchard tree), among others, as well as exotic varieties such as Eucaliptus sp. (eucalyptus) and Pinus sp. (pine tree) [24] on a trail about $50 \mathrm{~m}$ from a soccer field located between the administration building and the forest.

The Atlantic Forest fragment (S06 04'57.7"/W035 $\left.10^{\prime} 58.7^{\prime \prime}\right)$ and the pinery (S06 $\left.04^{\prime} 50.2^{\prime \prime} / \mathrm{W} 035^{\circ} 10^{\prime} 57.8^{\prime \prime}\right)$ are the best preserved areas of the forest, with little anthropic activity.

The third area (3), denominated forest, consists of medium-sized and large native trees, between 10 and $25 \mathrm{~m}$ high, whose main species are Bowdichia vigilioides (sucupira), Lecythis pisonis (cream nut), Buchenavia sp. (mirindimba), Tapirira guianenis (cupiúba), Myrcia sp. (pau mulato), Coccoloba sp. (cauaçu), Tocoyena sp. (juruparana), Hymenaea sp. (jatobá), Cassia apoucovita, C. ferrea (pau ferro), Tabebuia sp. (ipê), C. echinata (Brazilwood), B. forficata (Brazilian orchard tree), among others. It is considered a fragment of the Semideciduous Seasonal Forest at an advanced stage of regeneration, covering around 80 ha, $45.22 \%$ of FLONA's total area [24].

The fourth area (4), the pinery, is located in the experimental area for Atlantic Forest regeneration, involving the planting of exotic pine trees (Pinus sp.) [24]. 


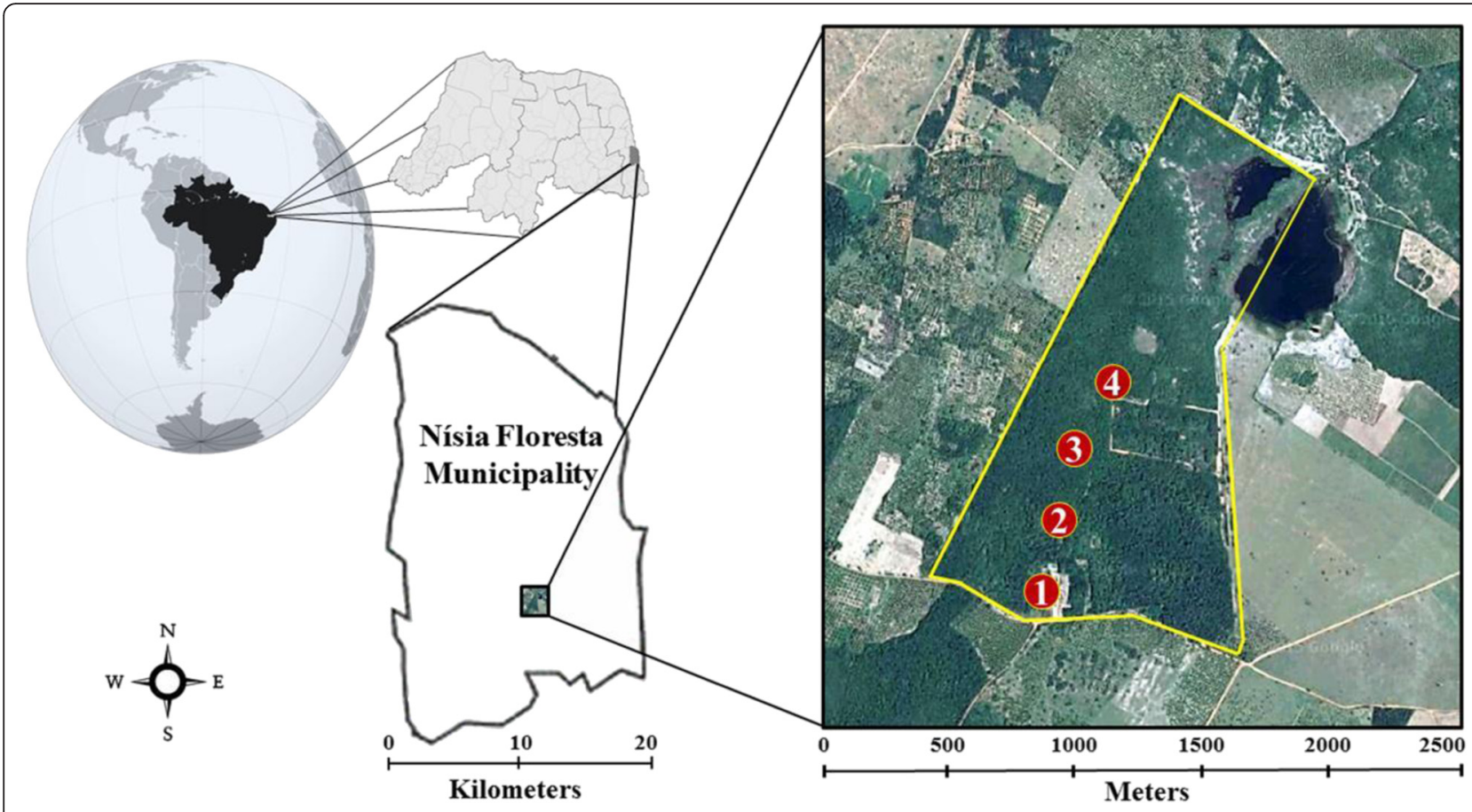

Fig. 1 Location of the municipality of Nísia Floresta and the Conservation Unit where collections took place

\section{Sandfly captures and identification}

Collections were carried out twice a month from May 2012 to April 2013, using a CDC (Center for Disease Control) light trap placed $1 \mathrm{~m}$ above the ground, activated at $5 \mathrm{pm}$ and removed at 7 am the following morning.

The insects were sacrificed and screened in the Entomology Laboratory of Universidade Federal do Rio Grande do Norte, at a temperature of $-20^{\circ} \mathrm{C}$.

The sand flies were then cleared in $10 \%$ potassium hydroxide $(\mathrm{KOH})$, mounted and observed under optical microscope for morphological identification, based on phylogenetic classification proposed by Galati [25, 26]. They were then cataloged and stored in the Professor Adalberto Antônio Varela-Freire Entomological Collection of Universidade Federal do Rio Grande do Norte.

\section{Statistical data analysis}

Analysis to determine and compare diversity between environments was conducted using the Shannon-Wiener Diversity Index ( $\left.\mathrm{H}^{\prime}\right)$ [27], calculated with Ecological Methodology 5.2 software [28].

The index of species abundance (ISA) and standardized index of species abundance (SISA) [29] were applied to analyze abundance data. The ISA values were determined and converted into SISA values between 0 and 1, using Microsoft Office Excel 2007.
The results were compared with rainfall, relative humidity and temperature data obtained from the National Meteorology Institute [30].

\section{Results}

A total of 2936 sand flies were collected from six genera belonging to the following ten species: Evandromyia walkeri, Evandromyia evandroi, P. wellcomei, Sciopemyia sordellii, Psathyromyia brasiliensis, L. longipalpis, Evandromyia lenti, Psathyromyia shannoni, N. whitmani and Nyssomyia intermedia (Table 1).

The environment containing the largest number of sand flies collected was the forest, accounting for $32.4 \%$ of the specimens, followed by bamboo and pinery, with $26.3 \%$ and $21.5 \%$ respectively, and trail with $19.8 \%$ (Table 1).

E. walkeri was the most abundant in each ecotope, corresponding to $77.6 \%$ of all sand flies collected (SISA = 1.0), followed by $E$. evandroi with $17.5 \%(\mathrm{SISA}=0.87)($ Fig. 2). The least abundant species were $N$. whitmani $($ SISA $=0.04$ ) and $N$. intermedia (SISA $=0.04$ ) (Table 1$)$.

The collection site with the greatest diversity, according to the Shannon Diversity Index $\left(\mathrm{H}^{\prime}\right)$, was the pinery $\left(\mathrm{H}^{\prime}=1.097\right)$, followed by forest $\left(\mathrm{H}^{\prime}=1.008\right)$ (Table 1$)$.

$P$. wellcomei was the most abundant at points of less anthropic activity, while L. longipalpis was the most common in areas of significant human intervention (Table 1) (Fig. 3). 
Table 1 Sand fly species collected in each ecotope, results of SISA and $\mathrm{H}^{\prime}$

\begin{tabular}{|c|c|c|c|c|c|c|c|c|}
\hline \multirow[t]{2}{*}{ Species } & \multicolumn{4}{|c|}{ Ecotopes } & \multirow[t]{2}{*}{ Total } & \multirow[t]{2}{*}{$\%$} & \multirow[t]{2}{*}{ SISA } & \multirow[t]{2}{*}{ Ranking } \\
\hline & Pinery & Forest & Trail & Bamboo & & & & \\
\hline Evandromyia walkeri & 456 & 779 & 473 & 589 & 2297 & $77.60 \%$ & 1.00 & 1 \\
\hline Evandromyia evandroi & 138 & 118 & 80 & 159 & 495 & $17.50 \%$ & 0.87 & 2 \\
\hline Psychodopygus wellcomei & 11 & 32 & 8 & 3 & 54 & $1.90 \%$ & 0.82 & 3 \\
\hline Sciopemyia sordellii & 4 & 13 & 6 & 3 & 26 & $0.86 \%$ & 0.81 & 4 \\
\hline Lutzomyia longipalpis & 1 & 3 & 6 & 9 & 19 & $0.64 \%$ & 0.80 & 5 \\
\hline Evandromyia lenti & 2 & 3 & 4 & 1 & 10 & $0.34 \%$ & 0.79 & 6 \\
\hline Psathyromyia brasiliensis & 10 & 6 & 6 & 0 & 22 & $0.73 \%$ & 0.56 & 7 \\
\hline Psathyromyia shannoni & 0 & 1 & 1 & 7 & 9 & $0.30 \%$ & 0.54 & 8 \\
\hline Nyssomyia whitmani & 0 & 3 & 0 & 0 & 3 & $0.10 \%$ & 0.04 & 9 \\
\hline Nyssomyia intermedia & 0 & 1 & 0 & 0 & 1 & $0.03 \%$ & 0.04 & 10 \\
\hline Total & 622 & 959 & 584 & 771 & 2936 & $100 \%$ & - & - \\
\hline$\%$ & $21.5 \%$ & $32.4 \%$ & $19.8 \%$ & $26.3 \%$ & $100 \%$ & - & - & - \\
\hline $\mathrm{H}^{\prime}$ & 1.097 & 1.008 & 0.993 & 0.978 & - & - & - & - \\
\hline
\end{tabular}

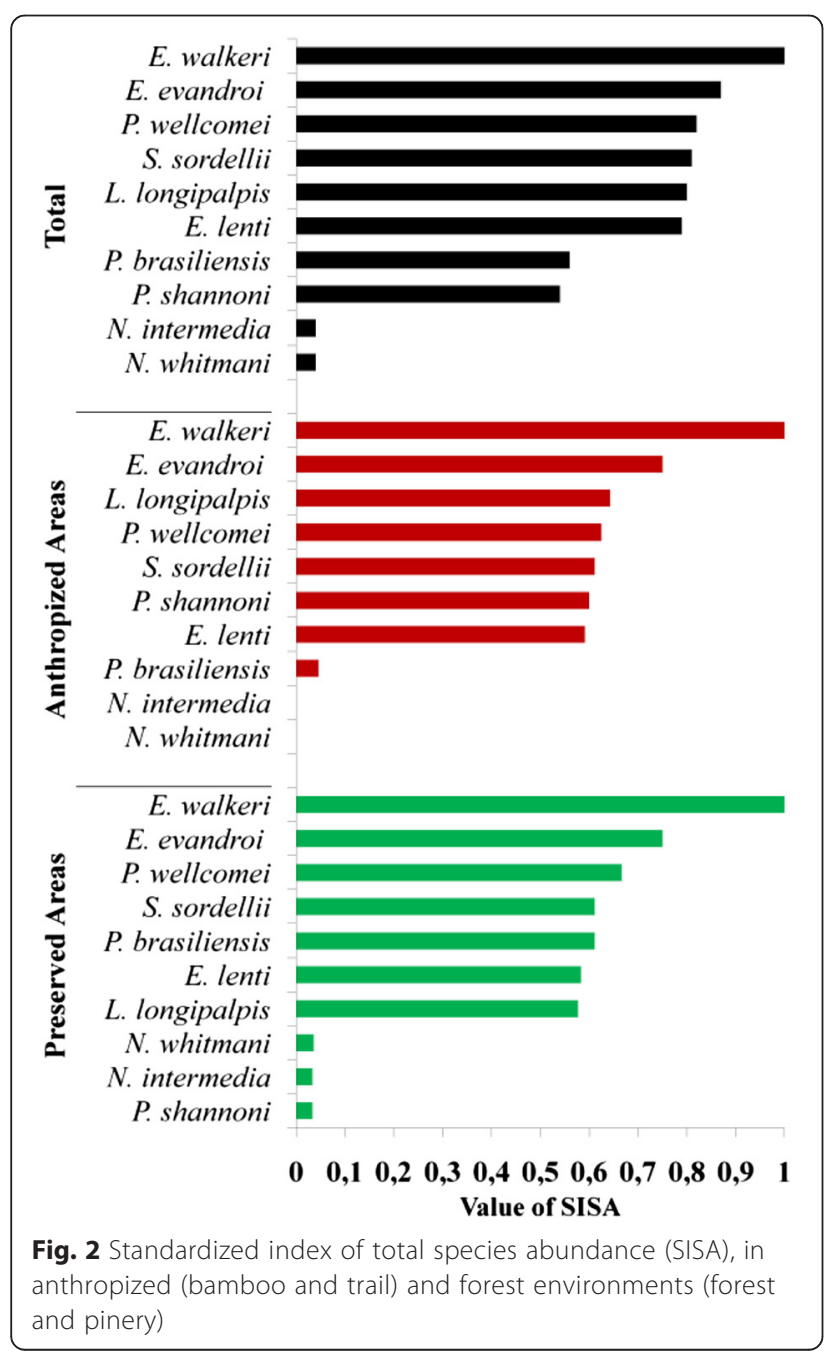

The largest number of sand flies were collected in May 2012 (33.7 \% of the captures), and the lowest in April 2013, with only five specimens, four E. evandroi and one E. walkeri (Table 2).

In all collection months, the species with the highest density were E. walkeri and E. evandroi (Table 2). P. wellcomei was the third most collected species in May, June, July, August and February (Table 2), months when considerable rainfall occurs (Fig. 4). There was a tendency for a larger number of sand flies of most species in the rainy months (Table 2).

\section{Discussion}

The most abundant species collected were E. walkeri and E. evandroi, as yet not identified as vectors of Leishmania. However, the presence of vectors such as $L$.

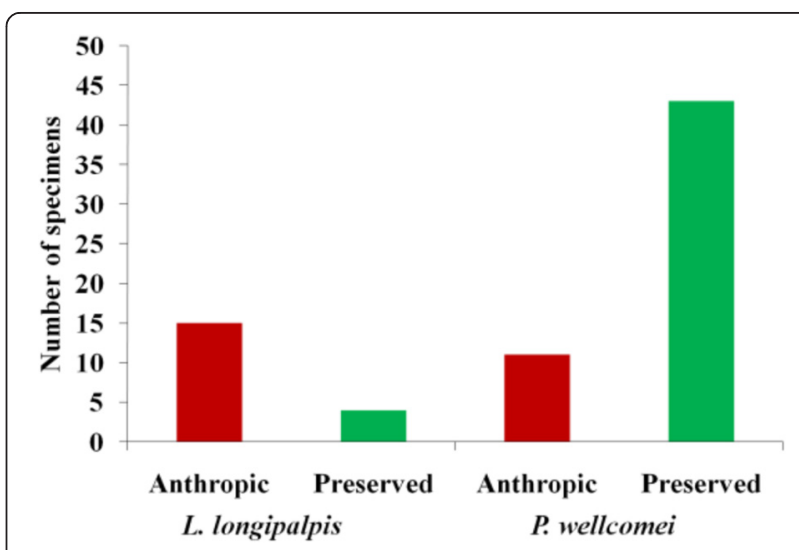

Fig. 3 Occurrence of L. longipalpis and P. wellcomei in anthropized (bamboo and trail) and forest environments (forest and pinery) 
Table 2 Sand fly species collected monthly at the Conservation Unit

\begin{tabular}{|c|c|c|c|c|c|c|c|c|c|c|c|c|c|}
\hline \multirow[t]{2}{*}{ Species } & \multicolumn{12}{|c|}{ Month } & \multirow[t]{2}{*}{ Total } \\
\hline & May & Jun & Jul & Aug & Sep & Oct & Nov & Dec & Jan & Feb & Mar & $\mathrm{Apr}$ & \\
\hline Evandromyia walkeri & 863 & 156 & 299 & 86 & 80 & 90 & 142 & 68 & 92 & 300 & 120 & 1 & 2297 \\
\hline Evandromyia evandroi & 87 & 29 & 63 & 19 & 36 & 32 & 34 & 35 & 40 & 80 & 36 & 4 & 495 \\
\hline Psychodopygus wellcomei & 25 & 5 & 9 & 9 & 2 & 0 & 0 & 0 & 0 & 3 & 1 & 0 & 54 \\
\hline Sciopemyia sordellii & 10 & 0 & 4 & 2 & 3 & 4 & 1 & 0 & 0 & 1 & 1 & 0 & 26 \\
\hline Psathyromyia brasiliensis & 8 & 0 & 5 & 5 & 4 & 0 & 0 & 0 & 0 & 0 & 0 & 0 & 22 \\
\hline Lutzomyia longipalpis & 7 & 2 & 1 & 0 & 6 & 0 & 1 & 0 & 0 & 2 & 0 & 0 & 19 \\
\hline Evandromyia lenti & 5 & 0 & 0 & 1 & 0 & 1 & 0 & 2 & 1 & 0 & 0 & 0 & 10 \\
\hline Psathyromyia shannoni & 1 & 0 & 1 & 7 & 0 & 0 & 0 & 0 & 0 & 0 & 0 & 0 & 9 \\
\hline Nyssomyia whitmani & 0 & 0 & 2 & 0 & 1 & 0 & 0 & 0 & 0 & 0 & 0 & 0 & 3 \\
\hline Nyssomyia intermedia & 1 & 0 & 0 & 0 & 0 & 0 & 0 & 0 & 0 & 0 & 0 & 0 & 1 \\
\hline Total & 1007 & 192 & 384 & 129 & 132 & 127 & 178 & 105 & 133 & 386 & 158 & 5 & 2936 \\
\hline
\end{tabular}

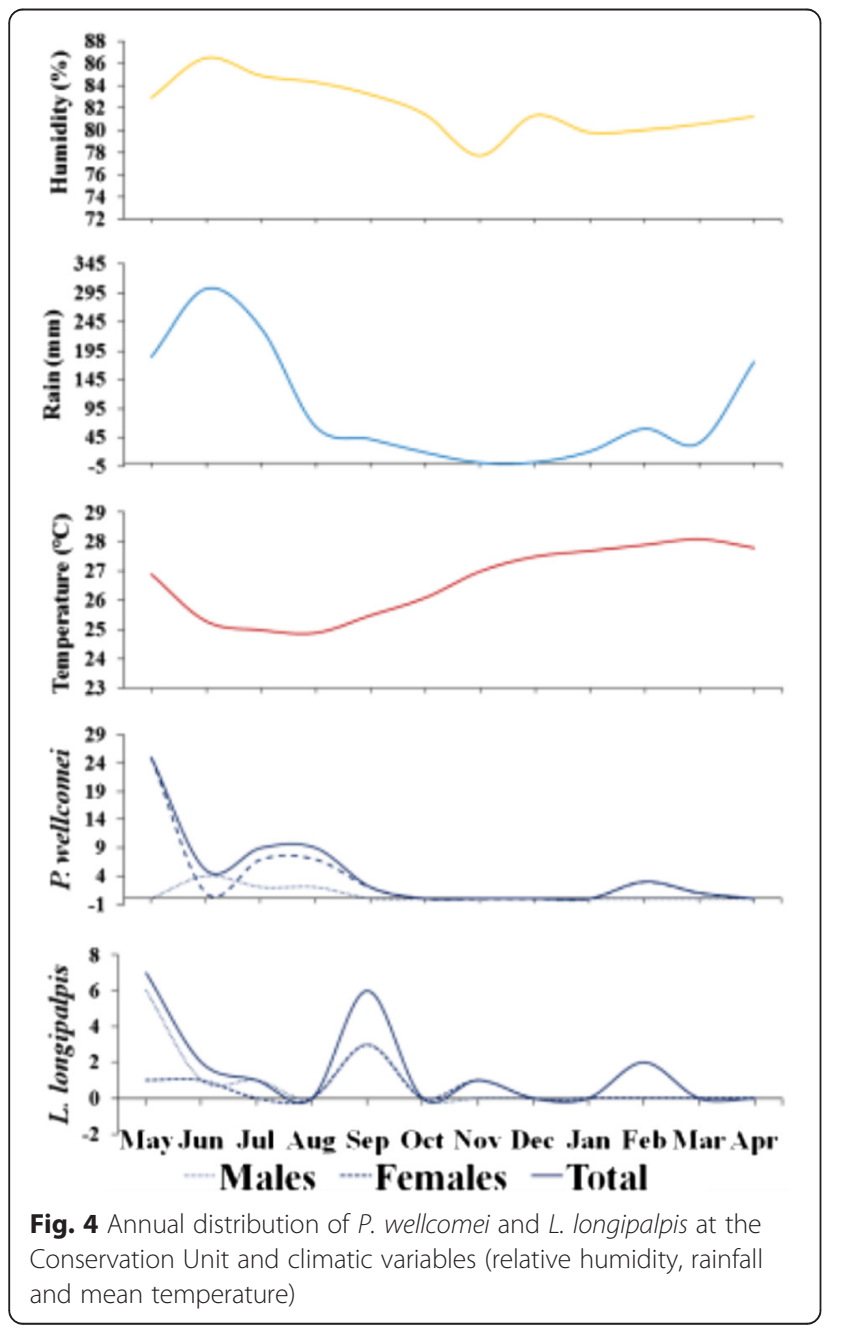

longipalpis, $N$. whitmani, $N$. intermedia and $P$. wellcomei is noteworthy.

Among sand fly vectors, there is an association between $L$. longipalpis, transmitter of $L$. infantum and modified environments, since most specimens were collected in this area. This is corroborated by numerous studies reporting the occurrence of these species in modified environments, evidencing their anthropophilic behavior [4, 31, 32].

$N$. whitmani and $N$. intermedia, species confirmed as vectors of $L$. braziliensis in forest environments in the Northeast [7, 13], and P. wellcomei, a vector species in Amazônia [33-35], have demonstrated a preference for more preserved areas of the Conservation Unit. P. wellcomei and $N$. whitmani are predominantly forest dwellers in the study areas, given that most of the captures of both species occurred in such environments. However, it is important to underscore the easy adaptation of $N$. whitmani to anthropized environments [36].

The study area exhibited a difference between the habitats of vector species of causative agents of ATL and $L$. longipalpis, transmitter of $L$. infantum, likely due to phytogeographic and biological factors. This difference was also suggested in studies conducted by other authors in Bahia state, where L. longipalpis occurs in areas of the Caatinga or in those with anthropic activity, whereas $N$. whitmani and $N$. intermedia are found in tropical forests $[32,37,38]$. This shows that some regions exhibit a likely association between ATLtransmitting species and forest environments, whereas $L$. longipalpis, a VL transmitter, is associated with Caatinga environments or degraded areas with anthropic activity.

The fact that L. longipalpis is more common in anthropized environments confirms the anthropophilic behavior of the species and is undoubtedly related to cases of human VL in the metropolitan region of Natal. A total of 799 cases of VL were diagnosed in Rio Grande 
do Norte state between 2007 and 2014, 297 in the metropolitan region [21]. Thus, the greater frquency of L. longipalpis in anthropized environments confirms the invasive potential of this species, as well as its success as a vector in urban areas.

P. wellcomei, the third most abundant species in this study, was initially found in the Brazilian Amazon [39] and later in the Northeast, in forests in Ceará state [33], forest and peridomiciliary environments in Maranhão state $[13,40]$, and in forest environments of metropolitan regions in the states of Pernambuco [35] and Rio Grande do Norte [15].

Although studies on $P$. wellcomei in Northeastern Brazil are not sufficient to consider it as a vector in the region [33-35], the occurrence of this species is extremely relevant, since it is a confirmed vector of $L$. braziliensis in Amazônia [39, 41] and exerts intense anthropofilia even in the daytime [42]. The endemic area of cutaneous leishmaniasis in Rio Grande do Norte is in the highland region of the state, the occurrence of this species in the metropolitan region, with greater abundance during some months of the year, reinforces the need for surveillance, given that residents, workers and researchers are in or near the forest on a daily basis.

In this study, $P$. wellcomei was associated with rainy months, corroborating the pattern described for the Amazon [8]. This leads us to suspect the possibility of diapause during the dry season, as reported in studies carried out in the Amazon [43]. Diapause seems to be a strategy adopted by sand flies to survive during adverse or extreme conditions [44].

Even though the study area is not endemic for ATL, it is important to register the occurrence of a small number of $N$. whitmani. This anthropophilic species is a vector of $L$. braziliensis in a number of areas in Brazil [9, 10, 45], including the Northeast [7], and its importance as a vector depends on its adaptation to the features of local ecotopes [46].

It is important to underscore the urban expansion at the edge of the Conservation Unit, where there has been an increase in residential condominiums. This interference may lead to the adaptation of vectors to new environments and alternative food sources, and at certain moments favor transmission cycles of the protozoan, as observed after colonization or deforestation [47-50].

The presence of predominantly forest-dwelling sand flies reported in this study indicates a certain persistence in survival, and consequent transmission potential, despite the growing environmental degradation that has occurred surrounding the study area. It is important to highlight the increasing adaptation of vector species to environments modified by man [51], which may contribute to maintaining the vector potential of these species.
Even though E. walkeri and E. evandroi are dominant in areas of the Conservation Unit with significant anthropic activity (bamboo and trail), the concomitant presence of $P$. wellcomei, a species more adapted to forest environments, and L. longipalpis, an urbanized species, is relevant. In this respect, the possibility of sand flies' seeking food in inhabited areas is important, as suggested in another study carried out in the metropolitan region of Natal, where these vectors may have adapted to feeding on exotic plants, whose monosaccharides coincided with those detected in plants such as Eucalyptus sp. (eucalyptus) and Pennisetum pupureum (elephant grass) [52].

P. shannoni was captured at three points: bamboo, trail and forest. In the United States, this species is considered a vector of Vesiculovirus, the cause of vesicular stomatitis [53], and a number of studies indicate that $L$. infantum develops well in this sand fly [54]. It is also hypothesized that the presence of infected dogs in occurrence areas of $P$. shannoni could give rise to epidemic cycles [55].

Given that expansion and urbanization of leishmaniases results from interactions between hosts and the protozoan parasite, as well as environmental degradation, studies aimed at analyzing the bioecology of vector species and their potential to adapt to new environments are sources of information that may contribute to the epidemiological surveillance of leishmaniases.

\section{Conclusions}

The rainiest period coincided with the highest occurrence of sand flies, and the greatest abundance and diversity was recorded in a preserved forest area.

There was a difference in species composition between the most anthropized and preserved areas.

It was confirmed that $P$. wellcomei is a species adapted to the rainiest period of the year and to forest environments, especially preserved areas. However, this species has been able to adapt to degraded environments, since in this study it also appears in environments with greater anthropic activity.

L. longipalpis seemed more adapted to areas with anthropic intervention; however, it can also be found in preserved environments.

\section{Abbreviations}

ATL: American tegumentary leishmaniasis; CDC: center for diseases control; FLONA: national forest; VL: visceral leishmaniasis.

\section{Competing interests}

The authors declare that they have no competing interests.

Authors' contributions

MPGP and MFFMX conceived the investigation. MPGP, MMMS, M.L.A., JBSJ and JHTS performed the fieldwork and identified the sandflies. MPGP, MLA, MMMS, JHTS, JBSJ and MFFMX analyzed the data and prepared the manuscript. All authors read and approved the final manuscript. 


\section{Authors' information}

MPGP and MLA are doctoral students in the Development and Environment Graduate Program (PRODEMA) of Universidade Federal do Rio Grande do Norte (UFRN). JHTS and MMMS are Masters students in the Biological Sciences Graduate Program (PPCB) of UFRN. JBSJ is a biologist. MFFMX is a professor and researcher in the Department of Microbiology and Parasitology of UFRN.

\section{Acknowledgments}

To the Chico Mendes Biodiversity Conservation Unit (ICMBio), and the management and employees at the National Forest of Nísia Floresta for their authorization and support.

To the Coordination for the Improvement of Higher Education Personnel (CAPES) and the National Council for Scientific and Technological Development (CNPq) for financial support.

\section{Received: 19 November 2015 Accepted: 29 January 2016} Published online: 11 February 2016

\section{References}

1. Desjeux P. Leishmaniasis: current situation and new perspectives. Comp Immunol Microbiol Infect Dis. 2004;27:305-18.

2. Rohousova I, Ozensoy S. Detection of species-specific antibody response of humans and mice bitten by sand flies. Parasitology. 2005;130:493-9.

3. Organização Pan-Americana da Saúde (PAHO). Informe Leishmanioses No 3 - Julho de 2015. http://www.paho.org/hq/index.php?option=com_ topics\&view=article\&id=29\&ltemid=40754. Accessed 08 Jan 2016.

4. Lainson R, Rangel EF. Lutzomyia longipalpis and the eco-epidemiology of American visceral leishmaniasis, with particular reference to Brazil - a review. Mem Inst Oswaldo Cruz. 2005;100:811-27.

5. Oliveira CC, Lacerda HG, Martins DR, Barbosa JD, Monteiro GR, Queiroz JW, et al. Changing epidemiology of American cutaneous leishmaniasis (ACL) in Brazil: a disease of the urban-rural interface. Acta Trop. 2004;90:155-62.

6. Azevedo ACR, Rangel EF, Queiroz RG. L. migonei (França, 1920) naturally infected with peripylarian flagellates in Baturité, a focus of cutaneous leishmaniasis in Ceará State, Brazil. Mem Inst Oswaldo Cruz. 1990:85:479.

7. Queiroz RG, Vasconcelos IA, Vasconcelos AW, Pessoa FA, Sousa RN, David JR. Cutaneous leishmaniasis in Ceará State in Northeastern Brazil: incrimination of Lutzomyia whitmani (Diptera: Psychodidae) as vector of Leishmania braziliensis in Baturité municipality. Am J Trop Med Hyg. 1994;50:693-8.

8. Lainson R, Shaw JJ. New World Leishmaniasis. The neotropical Leishmania species. In: Collier L, Ballows A, Sussman M, editors. Topley \& Wilson's microbiology and microbial infectious diseases. 9th ed. London: Arnold; 1998. p. 241-66.

9. Teodoro U, Alberton D, Kühl JB, Santos ES, Santos DR, Santos AR, et al. Ecologia de Lutzomyia (Nyssomyia) whitmani em área urbana do município de Maringá, Paraná. Rev Saude Publica. 2003:37:651-6.

10. Alessi CAC, Galati EAB, Alves JR, Corbett CEP. American cutaneous leishmaniasis in the Pontal of Paranapanema - SP, Brazil: ecological and entomological aspects. Rev Inst Med Trop Sao Paulo. 2009;51:277-82.

11. Diniz MMCSL, Ovallos FG, Gomes CMC, Lavitschka CO, Galati EAB. Hostbiting rate and susceptibility of some suspected vectors to Leishmania braziliensis. Parasit Vectors. 2014. doi:10.1186/1756-3305-7-139.

12. Freitas MTS, Ríos-Velasquez CM, Costa-Junior CRL, Fiqueiredo-Junior CAS Aragão NC, Silva LG, et al. Phenotypic and genotypic variations among three allopatric populations of Lutzomyia umbratilis, main vector of Leishmania guyanensis. Parasit Vectors. 2015. doi:10.1186/s13071-015-1051-7.

13. Rebêlo JMM, Araújo JAC, Carvalho ML, Barros VLL, Silva FS, Oliveira ST. Flebótomos (Diptera:Phlebotominae) da Ilha de São Luis, Zona do Golfão Maranhense, Brasil. Rev Soc Bras Med Trop. 1999;32:247-53.

14. Balbino VQ, Andrade MS, Coutinho-Abreu I, Sonoda IV, Marcondes CB, Shaw $J$ J, et al. Sand flies (Diptera: Psychodidae) in Pernambuco State, northeastern Brazil: The presence of species incriminated as vectors of cutaneous leishmaniasis in the Amazon region. Zootaxa. 2005;1078:25-32.

15. Pinheiro MPG, Silva JHT, Silva VPM, Andrade MJM, Ximenes MFFM. Lutzomya wellcomei Fraiha, Shaw \& Lainson (Diptera, Psychodidae, Phlebotominae) em Fragmento de Mata Atlântica do Rio Grande do Norte, Nordeste do Brasil. EntomoBrasilis. 2013;6:232-8.

16. Ximenes MFFM, Pinheiro MPG, Cavalcante KB, Silva VPM, Pontes NN Queiroz PV, et al. Urbanization of visceral leishmaniasis in Rio Grande do
Norte, Brazil: biotic and abiotic interactions. Rev Soc Bras Med Trop. 2009:42:138-40.

17. Casos confirmados de Leishmaniose Visceral, Brasil, Grandes Regiões e Unidades Federadas. Ministério da Saúde. Secretaria de Vigilância em Saúde, Brasil; 2015. http://portalsaude.saude.gov.br/images/pdf/2014/ setembro/09/LV-Casos.pdf. Accessed 7 Feb 2016.

18. Marzochi MCA. Leishmanioses no Brasil: as leishmanioses tegumentares. J Bras Med. 1992;63:82-104.

19. Vale ECS, Furtado T. Leishmaniose tegumentar no Brasil: revisão histórica da origem, expansão e etiologia. An Bras Dermatol. 2005;80:421-8.

20. Ximenes MFFM, Silva VPM, Queiroz PVS, Rego MM, Cortez AM, Batista LMM, et al. Flebotomíneos (Diptera: Psychodidae) e Leishmanioses no Rio Grande do Norte, Nordeste do Brasil - Reflexos do Ambiente Antrópico. Neotrop Entomol. 2007;36:128-37.

21. Secretaria de Estado da Saúde Pública do Rio Grande do Norte (SESAP) Sistema de Informação de Agravos de Notificação (SINAN). Leishmaniose tegumentar e Leishmaniose Visceral por Município de Residência no Estado do Rio Grande do Norte, Brasil: 2007-2014; 2015. http://sinan.saude.gov.br/ sinan. Accessed 7 Feb 2016.

22. Leite Al, Araújo LB. Leishmaniose visceral: aspectos epidemiológicos relacionados aos óbitos em Mossoró-RN. Rev Patol Trop. 2013:42:301-8.

23. Estimativa da População 2014, Nísia Floresta, Rio Grande do Norte, Brasil. Instituto Brasileiro de Geografia e Estatística (IBGE). 2015. http://www. cidades.ibge.gov.br/xtras/perfil.php?lang=\&codmun=2408201. Accessed 15 Jul 2015

24. Plano de Manejo da Floresta Nacional de Nísia Floresta (Volume I). Ministério do Meio Ambiente, Brasília, Brasil. 2015. http://www.icmbio.gov. br/portal/images/stories/imgs-unidades-coservacao/Nolume_I_Diagn\% C3\%B3stico_02ago12.pdf. Accessed 05 Aug 2015.

25. Galati EAB. Classificação de Phlebotominae. In: Rangel EF, Lainson R, editors. Flebotomíneos do Brasil. Rio de Janeiro: Editora Fiocruz; 2003. p. 23-51.

26. Galati EAB. Morfologia e Taxonomia: Morfologia, terminologia de adultos e identificação dos táxons da América. In: Rangel EF, Lainson R, editors. Flebotomíneos do Brasil. Rio de Janeiro: Editora Fiocruz; 2003. p. 53-175.

27. Magurran AE. Ecological diversity and its measurement. London: Cambridge University Press; 1988. p. 179.

28. Kenney AJ, Krebs CJ. Programs for Ecological Methodology. 2nd ed. Vancouver: University of British Columbia; 2000.

29. Roberts DR, Hsi BP. An index of species abundance for use with mosquito surveillance data. Environ Entomol. 1979:8:1007-13.

30. Instituto Nacional de Meteorologia (INMET). Banco de Dados Meteorológicos para Ensino e Pesquisa. 2015. http://www.inmet.gov.br/ portal/index.php?r=bdmep/bdmep. Accessed 12 Jun 2015.

31. Ximenes MFFM, Castellon EG, Souza MF, Freitas RA, Pearson RD, Wilson ME, et al. Distribuition of phlebotomine sandflies (Diptera: Psychodidae) in the state of Rio Grande do Norte, Brazil. J Med Entomol. 2000;37:162-9.

32. Dias-Lima AG, Guedes MLS, Sherlock IA. Horizontal Stratification of the Sand Fly Fauna (Diptera: Psychodidae) in a Transitional Vegetation between Caatinga and Tropical Rain Forest, State of Bahia, Brazil. Mem Inst Oswaldo Cruz. 2003;98:733-7

33. Ready PD, Ribeiro AL, Lainson R, Alencar JE, Shaw JJ. Presence of Psychodopygus wellcomei (Diptera: Psychodidae), a proven vector of Leishmania braziliensis, in Ceará State. Mem Inst Oswaldo Cruz. 1983;78:235-6

34. Brandão-Filho SP, Brito MEF, Martins CAP, Sommer IB, Valença HF, Almeida FA, et al. Leishmaniose tegumentar americana em centro de treinamento militar localizado na Zona da Mata de Pernambuco, Brasil. Rev Soc Bras Med Trop. 1998;31:575-8.

35. Silva DF, Vasconcelos SD. Flebotomíneos em fragmentos de Mata Atlântica na Região Metropolitana do Recife, PE. Rev Soc Bras Med Trop. 2005:38:264-6.

36. Brandao-Filho SP, Donalisio MR, Silva FJ, Valenca HF, Costa PL, Shaw JJ, et al. Spatial and temporal patterns of occurrence of Lutzomyia sand fly species in an endemic area for cutaneous leishmaniasis in the Atlantic Forest region of Northeast Brazil. J Vector Ecol. 2011;36 Suppl 1:71-6.

37. Vexenat JA, Barreto AC, Cuba CAC, Marsden PD. Características epidemiológicas da leishmaniose tegumentar americana em uma região endêmica do estado da Bahia. III. Fauna flebotomínica. Mem Inst Oswaldo Cruz. 1986;81:293-301.

38. Azevedo ACR, Vilela ML, Souza NA Coelho CAA, Barbosa AF, Firmo ALS, et al. The sand fly fauna (Diptera: Psychodidae: Phlebotominae) of a focus 
cutaneous of leishmaniases in llheus, state of Bahia, Brazil. Mem Inst Oswaldo Cruz. 1996;91:75-9.

39. Lainson R, Shaw JJ, Ward RD, Fraiha H. Leishmaniasis in Brazil: IX Considerations on the Leishmania braziliensis complex: Importance of the genus Psychodopygus Mangabeira in the transmission of $L$. braziliensis brasiliensis in north Brazil. Trans R Soc Trop Med Hyg. 1973;67:184-96.

40. Pereira-Filho AA, Bandeira MCA, Fonteles RS, Moraes JLP, Lopes CRG, Melo MN, et al. An ecological study of sand flies (Diptera: Psychodidae) in the vicinity of Lençóis Maranhenses National Park, Maranhão, Brazil. Parasit Vectors. 2015. doi:10.1186/s13071-015-1045-5.

41. Ryan L, Lainson R, Shaw JJ. Leishmaniasis in Brazil. XXIV. Natural flagellate infections of sandflies (Diptera: Psychodidae) in Pará State, with particular reference to the role of Psychodopygus wellcomei as the vector of Leishmania braziliensis in the Serra do Carajás. Trans R Soc Trop Med Hyg. 1987;81:353-9.

42. Fraiha H, Shaw JJ, Phlebotominae LR, Brasileiros II. Psychodopygus wellcomei, nova espécie antropófila de flebótomo do grupo squamiventris, do sul do estado do Pará, Brasil (Diptera: Psychodidae). Mem Inst Oswaldo Cruz. 1971;69:489-500.

43. Ryan L, Lainson R, Shaw JJ, Fraiha-Neto H. Ecologia de flebotomíneos (Diptera, Psychodidae, Phlebotominae) na Região Amazônica, vol. 1. Belém: Instituto Evandro Chagas "50 anos"; 1987. p. 307-20.

44. Lawyer PG, Young DG. Diapause and quiescence in the neotropical sand fly Lutzomyia diabolica (Hall). Parassitologia. 1992;33:353-60.

45. Costa SM, Cechinel M, Bandeira V, Zannuncio JC, Lainson R, Rangel EF. Lutzomyia (Nyssomyia) whitmani s.l. (Antunes \& Coutinho, 1939) (Diptera: Psychodidae: Phlebotominae): geographical distribution and the epidemiology of American cutaneous leishmaniasis in Brazil - mini-review. Mem Inst Oswaldo Cruz. 2007;102:149-53.

46. Rebêlo JMM, Rocha RV, Moraes JLP, Alves GA, Leonardo FS. Distribuição de Lutzomyia whitmani em fitorregiões do estado do Maranhão, Brasil. Rev Saude Publica. 2009;43(6):1070-4.

47. Costa JML, Saldanha ACR, Mello-Silva AC, Serra-Neto A, Galvão CES, Pedroso-Silva CM, et al. Estado atual da leishmaniose cutânea difusa (LCD) no Estado do Maranhão. II. Aspectos epidemiológicos, clínicos e evolutivos. Rev Soc Bras Med Trop. 1992;25:115-23.

48. Rebêlo JMM, Leonardo FS, Costa JML, Pereira YNO, Silva FS. Flebotomíneos (Diptera, Psychodidae) de área endêmica de leishmaniose na região dos cerrados, Estado do Maranhão, Brasil. Cad Saude Publica. 1999;15:623-30.

49. Rebêlo JMM, Oliveira ST, Barros VLL, Silva FS, Costa JML, Ferreira LA, et al. Phlebotominae (Diptera:Psychodidae) de Lagoas, município de Buriticupu, Amazônia Maranhense. I - Riqueza e abundancia relativa das espécies em área de colonização recente. Rev Soc Bras Med Trop. 2000;33:11-9.

50. Bern C, Maguire JH, Alvar J. Complexities of Assessing Disease Burden Attributable to Leishmaniasis. Negl Trop Dis. 2008;313:1-8.

51. Lainson R, Shaw JJ, Ready PD, Miles MA, Póvoa M. Leishmaniasis in Brazil: XVI. Isolation and identification of Leishmania species from sandflies, wild mammals and man in north Para State, with particular reference to Leishmania braziliensis guayanensis, causative agent of "pian-bois". Trans R Soc Trop Med Hyg. 1981;75:530-6.

52. Pinheiro MPG, Silva JHT, Cavalcanti KB, Azevedo PRM, Ximenes MFFM. Ecological interactions among phlebotomines (Diptera: Psychodidae) in an Agroforestry environment of northeast Brazil. J Vector Ecol. 2013;38:307-16.

53. Corn JL, Comer JA, Erickson GA, Nettles VF. Isolation of vesicular stomatitis virus New Jersey serotype from phlebotomine sand flies in Georgia. Am J Trop Med Hyg. 1990;42:476-82.

54. Ferro C, Cardenas E, Corredor D, Morales A, Munstermann LE. Life cycle and fecundity analysis of Lutzomyia shannoni (Dyar) (Diptera: Psychodidae). Mem Inst Oswaldo Cruz. 1998;93:195-9.

55. Travi BL, Ferro C, Cadena H, Montoya-Lerma J, Adler GH. Canine visceral leishmaniasis: dog infectivity to sand flies from non-endemic areas. Res Vet Sci. 2002;72:83-6.

\section{Submit your next manuscript to BioMed Central and we will help you at every step:}

- We accept pre-submission inquiries

- Our selector tool helps you to find the most relevant journal

- We provide round the clock customer support

- Convenient online submission

- Thorough peer review

- Inclusion in PubMed and all major indexing services

- Maximum visibility for your research

Submit your manuscript at www.biomedcentral.com/submit
() BioMed Central 